\title{
Reflections On Service-Learning, Critical Thinking, And Cultural Competence
}

Lynette R. Goldberg, Wichita State University, USA

Kathy L. Coufal, Wichita State University, USA

\begin{abstract}
In today's increasingly multicultural society, students need to be prepared for the work world they will encounter. Well-developed critical thinking skills appear essential to needed cultural competence. With its focus on community involvement, deep reflection and civic engagement, the possibility that Service-Learning (SL) could improve students' critical thinking abilities, and thus contribute to students' intellectual development and cultural competence, was explored. The critical thinking abilities of a group of $4^{\text {th }}$ and $5^{\text {th }}$ year university students were measured before and after 12 weeks of community-based experiences. The $4^{\text {th }}$ year students were involved in an integrated SL course. The $5^{\text {th }}$ year students had completed the SL course the previous year. There was a significant difference between the two groups with the $5^{\text {th }}$ year students better able to think critically, particularly in deducing conclusions and evaluating arguments. Both quantitative and qualitative data from the two groups revealed a non-linear developmental trajectory of skills that provide insights for professionals in higher education.
\end{abstract}

Keywords: Service-learning, reflective practice, teaching, critical thinking, cultural competence

\section{INTRODUCTION}



ervice-Learning (SL) is an increasingly accepted tool that can provide culturally-relevant teaching and deep, experiential learning (Clayton \& Ash, 2004; Gelmon, 2007; Litke, 2002; Settle \& Smith, 2008; Zinger \& Sinclair, 2008). It has been effective in exposing students to diversity and positively changing prejudices (Boyte, 2006; Cornell-Swanson, 2006; Escalera, 2006; Huston, 2006). The SL approach integrates academic content, community partnership, and civic engagement (Goldberg, McCormick Richburg, \& Wood, 2006; Goldberg, 2007). The civic engagement is designed to increase students' understanding of the environmental, sociological, and political contexts of issues and theories addressed in the classroom. It helps sustain a high level of curiosity and enthusiasm as students encounter new, often challenging, ideas. It encourages students to see their own intellectual work as valuable. It is predicated upon their attitudes and values, knowledge, habits, and political behavior. It also is influenced by the clarity and intention of course instructors.

The effects of SL can be difficult to measure (Litke, 2002). However, when implemented effectively, SL may assist in counteracting the skepticism many people, including students, express about the approach of higher education to learning, to recognizing and valuing diversity, and to preparing students for the global workforce (Clydesdale, 2009; Kirsch, Braun, \& Yamamoto, 2007; Smith-Campbell, 2005; United States Department of Education, 2006).

The majority of today's university students, variously termed the net generation, millennials, echo boomers, the iGeneration, or digital natives, have been shown to be remarkably accepting of diversity, open to experimentation, and comfortable working in teams (Howe \& Strauss, 2000; Oblinger \& Oblinger, 2005). These students are demonstrably more attuned to inductive discovery, although such discovery initially may be narrow in perspective. They share a need for rapid responses, enjoy activities that involve frequent shifts in attention, and delight in multitasking. Even though they may be disengaged from traditional pedagogies, they attend class and endeavor to comply with traditional teaching approaches (Clydesdale, 2009). These students are ripe for creative learning/teaching approaches that embrace and respect their knowledge and skills. Service-Learning may serve as 
one creative approach to build on cultural awareness and acceptance and to facilitate engagement and critical thinking skills.

Critical thinking can be defined as the ability to broaden and deepen one's thinking through systematic intellectual self-assessment, internal reflection and collaborative validation (Eyler \& Giles, 1999; Garrison, 1992; Gokhale, 1995; Hatcher \& Bringle, 1997; Kolb, 1984; Paul \& Elder, 2008). It involves being able to (a) recognize and define a problem, (b) evaluate all available evidence, (c) recognize stated and unstated assumptions, and (d) draw valid conclusions to determine an appropriate solution. An additional aspect is dealing with the complex issue of emotion (Felten, Gilchrist, \& Darby, 2006). Thoughts and decisions are based on evidence or sound reasoning (Mezirow, 1990) rather than on "force, chance, or custom" (Langsdorf, 1988, p. 45) and facilitated through discussions in communities of learning (Garrison, 1992; Gokhale, 1995; Paul, Binker, Martin, Vetrano \& Kreklau, 1995). Through shared responsibility and ownership of the learning process, students learn how to think, rather than what to think (Carnegie Report, 2006).

Gains in critical thinking occur when individuals are able to critically consider reality and tolerate perplexity (Dewey, 1933; Freire, 1993). Critical thinking abilities appear essential to cultural competence, i.e., the cultural awareness, knowledge, intelligence, and sensitivity one brings to any situation (Cheng, 2005). Exposure to people whose backgrounds are different from one's own is a key component in facilitating cultural competence (Good, 2005; Gurin, Dey, Hurtado, \& Gurin, 2002; National Center for Cultural Competence, http://www11.georgetown.edu/research/gucchd/nccc/index.html, accessed June 11, 2009). This exposure needs to include education about the visible (e.g., race, ethnicity, gender, age, and disability) and invisible (e.g., sexual orientation and religion), forms of cultural diversity, including variations within cultures (Bowen \& Blackmon, 2003; Laroche, 2002). Individuals who are culturally competent are aware of their assumptions or prejudices, able to analyze and interpret differing arguments, and to make insightful and informed decisions. Measuring students' critical thinking thus may be an important component of exploring their understanding and appreciation of cultural diversity and their cultural competence.

The most effective way in which to measure critical thinking abilities remains open to debate. Recently, Landis, Swain, Friehe, and Coufal (2007) compared two theoretically-based approaches by analyzing students' narratives in classroom-based and on-line activities. The two approaches (the Newman method; Newman, Johnson, Cochrane, \& Webb, 1996, and the Facione rubric; Facione \& Facione, 1994) were evaluated by teams of educators. Although both appeared to have face and construct validity, Landis et al. (2007) were unable to establish inter-rater reliability for either. Further, the Newman method was perceived as unduly time-consuming and the Facione rubric too vague. In 2004, Bringle, Phillips and Hudson evaluated a number of tools purported to evaluate students' critical thinking and recommended the use of the Watson-Glaser Critical Thinking Appraisal (Watson \& Glaser, 1980). This test has two forms with strong test-retest reliability. It is considered a valid and reliable measure of attitudes, motives, values, moral conduct, and critical thinking. It consists of five subtests, each with 16 questions. These subtests measure the ability to (a) discriminate between true and false inferences, (b) recognize assumptions, (c) form appropriate deductions, (d) correctly interpret evidence for conclusions, and (e) evaluate the strength and relevancy of arguments. The Watson-Glaser test thus appeared appropriate to evaluate the critical thinking abilities of university students as a possible indicator of these students' cultural competence. The purpose of this pilot study was to use this test, along with an analysis of students' reflective comments, to explore the effects of diversityfocused Service-Learning experiences on students' critical thinking abilities and their cultural competence.

\section{METHOD}

\section{Participants}

Two groups of participants are detailed for comparison. Group A was comprised of 16 female students (mean age $=24.4$ years; range $22.02-38.01$ years) in their first year $\left(5^{\text {th }}\right.$ year at university) of a graduate program in Communication Sciences and Disorders (CSD). The cultural background of these participants was Caucasian $(\mathrm{n}=14)$, African American $(\mathrm{n}=1)$ and Native American $(\mathrm{n}=1)$. Each student had completed the diversity-focused SL course during the previous year as a 4th year undergraduate student and was familiar with keeping a reflective journal. These students currently were enrolled in a course on swallowing disorders. As a course requirement, each 
spent at least 15 hours in the community with children or adults with swallowing problems and maintained a weekly reflective journal on the experience.

Group B was comprised of 32 female undergraduate students (mean age $=21.11$ years; range 21.02 -23.11 years) in their $4^{\text {th }}$ (senior) year of a CSD program. The cultural background of these participants was Caucasian $(\mathrm{n}=29)$, African American $(\mathrm{n}=1)$, Native American $(\mathrm{n}=1)$, and Mexican $(\mathrm{n}=1)$. They currently were enrolled in the integrated SL course and placed with community partners for 12 weeks during the 16 -week semester. The course was a required component of the students' program of study. The students were aware of the SL nature of the course through the description in the curriculum catalogue, its on-line posting, and input from their curriculum advisor.

The two groups met the criteria for comparative studies to advance the analysis of SL (Carnegie Report, 2006). All participants were taught by the same instructor. The study was approved by the University's Institutional Review Board. All participants gave informed written consent prior to any data collection.

\section{Community placements}

The $5^{\text {th }}$ year students were placed at schools, hospitals, rehabilitation centers, assisted living facilities, and out-patient facilities that provided services to children or adults with swallowing disorders. Placements were organized by the Clinical Services Director within the CSD department and the instructor.

Community placements for the $4^{\text {th }}$ year students were organized by the director of the university's Citizenship and Service-Learning (CASL) office in collaboration with the course instructor. Placements were selected to increase students' awareness of the broad nature of diversity. At the beginning of the course, the $4^{\text {th }}$ year students were given a list of available placements, the mission statement for each organization, a description of the program(s) offered by each organization, and asked to select three they preferred. Placements included (a) an organization to integrate Hispanic families into the community and provide after-school care, (b) a shelter for people who were homeless, (c) support services for persons with HIV/AIDS, (d) nursing homes for the elderly, (e) Head Start programs for disadvantaged children, (f) a substance abuse program for parents and their affected babies, (g) a school for children with hearing loss, and (h) a therapeutic horseback riding program for children with sensorymovement difficulties. There were $12 \mathrm{SL}$ sites in all, with three students at 10 of the SL sites, and 2 students at one of the sites. All students were able to be placed at their first or second choice. Each student was required to complete a minimum of 15 SL hours.

The forms of community service varied according to the needs of the community partners but each partner's need was appropriate to the content of the students' course. Site supervisors were oriented to the clinical objectives and content of the swallowing course in a group meeting with the clinic director (on campus) and in individual meetings with the course instructor and the clinic director (at each site). Site supervisors were oriented to the expectations and content of the SL course in a group meeting with the CASL Director (on campus) and in individual meetings with the course instructor and the CASL director (at each site). Prior to beginning their community experience, each group of students completed a 60-minute orientation with the instructor on campus.

\section{Assessment Measures}

Participants in both groups completed the following measures: (a) course quizzes and exams, (b) reflective journals with weekly entries, and (c) pre- and post-course administration of the Watson-Glaser Critical Thinking Appraisal (Watson \& Glaser, 1980). The $5^{\text {th }}$ year students also completed pre- and post- self-report questionnaires that assessed their competency regarding swallowing disorders, and the $4^{\text {th }}$ year students completed a post-course CASL questionnaire.

\section{Procedures}

All participants completed three weeks of coursework and the orientation to their community experience prior to beginning their community-based interactions. They completed form A of the Watson-Glaser test in one 60-minute class period in week two, and Form B in one 60-minute class period in week 16. The community 
experiences were completed over weeks 4-15. All participants maintained a weekly journal. Journal entries were free form but written using the framework of Eyler and Giles (1999), specifically: "What did you see and do?" "How did you feel?" "Did any of your assumptions or beliefs change as a result of this experience?" and "How does what you experienced relate to what you are learning in class?" Students submitted these weekly journals on-line through a Discussion Board developed for each of the two courses. The instructor read the entries, responded online, and used the points raised by the students to facilitate ongoing discussions.

\section{Data Analysis}

A correct answer to each question in the five subtests of the Watson-Glaser instrument was given 1 point. A maximum score of 16 was possible for each subtest with a maximum score of 80 possible for each test administration. Data were entered using Statistical Package for the Social Sciences (SPSS) software, version 15.0 for Windows. Descriptive statistics were calculated, and paired $t$-test comparisons were run to assess within group differences. Univariate Analyses of Variance (ANOVA) with repeated measures were run to assess differences between the two groups. The possible effect of age on the students' critical thinking scores was examined. The dependent variables were the students' overall critical thinking scores and their scores on each of the five subtests. The independent variable was the SL experience (previous with continued community interaction and reflection, or current).

In a separate analysis at the end of the semester, two independent reviewers read each reflective journal to identify the primary concept in each statement and to develop a frequency count of statements regarding emotions, assumptions and challenges for a between-group comparison of these three categories. Data were analysed descriptively. The coding was a posteriori in nature, i.e., the students were not given the three specific categories at the beginning of the study to address in their journals.

\section{RESULTS}

There were no statistically significant differences in the critical thinking abilities of participants in Group A $(t=0.69, d f=15, p=0.50)$ or Group B $(t=0.65, d f=30, p=0.52)$ before and after community experiences. Pearson $r$ correlation coefficients were run to correlate age with each of the dependent variables to determine whether the age of each student group was a factor in the ANOVAs. There was no statistically significant relationship of age to any of the components of critical thinking ( $p$ values ranged from 0.12 to 0.75 ). Thus there was no need to consider the factor of age as a covariate in the ANOVAs (Stevens, 2002).

Results of the repeated measures ANOVAs showed a significant overall difference in critical thinking ability between the two groups $(F=4.25, d f=1,44 ; p=0.05)$. The $5^{\text {th }}$ year students (Group A) scored higher in overall critical thinking abilities, both pre-and post community experiences, than the $4^{\text {th }}$ year students (Group B). In addition, the $5^{\text {th }}$ year students were significantly better in their ability to deduce appropriate conclusions $(F=4.15, d f$ $=1,44 ; p=0.05)$ and to evaluate arguments $(F=5.53, d f=1,44 ; p=0.02)$. The ability of the $4^{\text {th }}$ year students to make accurate deductions decreased significantly after their SL experience (pre-SL Mean=11.23, post-SL Mean=10.07; $t$ $=2.21, d f=29, p=0.04)$. The $4^{\text {th }}$ year students' ability to recognize assumptions also decreased notably after their SL experience (pre-SL Mean=12.47, post-SL Mean=10.63; $t=2.88, d f=29, p=0.01$ ). With regard to evaluating the relevancy and strength of arguments, the ability of the $4^{\text {th }}$ year students increased following their SL experience (pre-SL Mean=11.87, post-SL Mean=12.23). However, this increase was not statistically significant and less than that of the $5^{\text {th }}$ year students (pre-community experience Mean= 13.25, post-Mean=13.00). Comparison data for Groups A and B are presented in Table 1. Pre- and post community experience data for both groups are illustrated in Figure 1. The trajectory of critical thinking abilities across the five subtests was remarkably similar for both groups pre- and post-community experience. 
Table 1. Repeated measures univariate ANOVAs for $5^{\text {th }}$ (Group A) and $4^{\text {th }}$ (Group B) year students

\begin{tabular}{|c|c|c|c|c|}
\hline Subtest & $d f$ & Mean Square & $F$ & Level of Significance \\
\hline \multicolumn{5}{|l|}{ Group } \\
\hline $\begin{array}{l}\text { Inference } \\
\text { Error }\end{array}$ & $\begin{array}{c}1 \\
44\end{array}$ & $\begin{array}{l}1.30 \\
7.93\end{array}$ & 0.16 & 0.69 \\
\hline $\begin{array}{l}\text { Recognition of } \\
\text { Assumptions } \\
\text { Error }\end{array}$ & $\begin{array}{c}1 \\
44\end{array}$ & $\begin{array}{l}22.74 \\
17.67\end{array}$ & 1.29 & 0.26 \\
\hline $\begin{array}{l}\text { Deduction } \\
\text { Error }\end{array}$ & $\begin{array}{c}1 \\
44 \\
\end{array}$ & $\begin{array}{c}39.82 \\
9.61\end{array}$ & 4.15 & $0.05 *$ \\
\hline $\begin{array}{l}\text { Interpretation } \\
\text { Error }\end{array}$ & $\begin{array}{c}1 \\
44\end{array}$ & $\begin{array}{l}0.13 \\
6.31\end{array}$ & 0.02 & 0.89 \\
\hline $\begin{array}{l}\text { Evaluation of } \\
\text { Arguments } \\
\text { Error }\end{array}$ & $\begin{array}{c}1 \\
44\end{array}$ & $\begin{array}{c}24.12 \\
4.40\end{array}$ & 5.53 & $0.02 *$ \\
\hline $\begin{array}{l}\text { Total } \\
\text { Error }\end{array}$ & $\begin{array}{c}1 \\
44 \\
\end{array}$ & $\begin{array}{l}440.80 \\
129.99 \\
\end{array}$ & 4.25 & $0.05^{*}$ \\
\hline
\end{tabular}

$* p \leq 0.05$.



Figure 1

Critical thinking abilities of $5^{\text {th }}(n=16)$ and $4^{\text {th }}(n=32)$ year university students before and after community experience ( maximum points per subtest $=16$ )

Due to the a posteriori category allocation to students' journals, not all weekly entries addressed all three categories and data were limited. There was an obvious difference between the two groups in the content of their comments. The $5^{\text {th }}$ year students focused on their exposure to people with swallowing problems, healthcare-related work settings, and service-delivery models. The $4^{\text {th }}$ year students commented more directly on issues of diversity. The descriptive journal evidence from the $4^{\text {th }}$ year students documented increased ability to cross socioeconomic and cultural boundaries and to make more refined moral judgments for over half of the students. These new experiences resulted, in these cases, in students raising relevant questions and exhibiting openness to contradictory ideas, i.e., students' own biases against their experiences with different populations. As stereotypes were challenged, students considered their assumptions and wrote about their thoughts. Journal entries showed many students' movement from "unreflective thinker" to "practicing" or "advanced thinker" (Paul \& Elder, 2008). As an example, one student 
initially thought negatively about the accent of an Hispanic individual. In late semester journal writings, she reflected,

"My poor assumption initially was that the easiest way to reduce this accent was to work on the obvious "errors" as I mistakenly viewed them... Now I know that anyone who listens to a foreign speaker and automatically decides that the speaker is making mistakes has a biased opinion...I understand now that the attitude towards that accent needs to change rather than the accent itself."

Another student reflected on her experiences with a young man with HIV/AIDS. She wrote,

"In some ways I'm ashamed to look back at what I wrote when I first met him, and what I wrote didn't really address all the negative thoughts I had. But then I realize how much he has taught me about enjoying people as people rather than letting a disease get in the way. I still can't talk about this too much with a couple of my friends but I'm working on ways to get them to be more understanding."

A third example came from a student who worked with African American pre-school children and their families in a Headstart program. She wrote,

"I had such a stereotypical and faulty view of the reasons these children had difficulty learning. When I heard people talking about the increased rates of learning problems, juvenile delinquency, single parent families in the Black community and things like this, I just didn't think beyond race and didn't think I could do anything about helping the situation. I am so grateful for the time I've spent with these kids and their families. I've learned to focus on issues such as the impact of parents having to work multiple jobs, or not having easy access to public transport or available programs. I've learned about important supports in the community and, probably the most important thing is that I've learned to listen and enjoy collaborative problem-solving. I know frustrating issues will continue, but at least now I'm focused on the right stuff."

An informal evaluation of $4^{\text {th }}$ year students' interactive on-line comments showed that statements demonstrating deductive reasoning and multiple perspectives on a point of view were rare. Students frequently described what they were doing, asked questions, offered suggestions, and provided possible solutions, but did not spontaneously write in ways that facilitated critical thinking by challenging what others had written. For example,

Student A. "I have noticed that many children and teens are coming to the Center to translate for family members who do not speak English. I suspect many of you are in situations where you meet young people who have grown up bilingual and will be the first members of their families who will have an opportunity for higher education. These kids are perfect candidates to be future members of our collective professions. I'm looking for suggestions how to let them know about the possibilities open to them"

Student B. "I think this is very interesting. I was wondering if there are any issues such as privacy with having a family member translate when asking for health or medical assistance?"

Student C." Your comment about how frustrating the language gap is made me think about how to gather information to best understand the client."

Student D. "One man where I am brought his daughter for the first time. Whenever he had trouble with understanding what exactly we were asking of him, his daughter would translate what we said to him. She was probably only 10 years old but she had been learning English for five years and was very clear and proficient. It must be difficult to be 40 years old and have a daughter who knows more about what's going on than you do. He told me he always tries to get his daughter to help him study and he asks her questions, but she never wants to help him."

Student E. "You [Student A] made a great point about informing those kids who are bilingual about using the talent they have to consider a career in our field. It would be amazing if there was a program set-up through our 
department where we could encourage teens through a big sister/brother program. This could involve taking them with us to an organization where there is a need for bilingual speakers and working side by side."

\section{DISCUSSION}

The intent of this pilot study was to determine whether a diversity-focused SL experience had an effect on students' critical thinking abilities and, therefore, on their readiness for working in an increasingly multicultural society. To examine this intent, the critical thinking abilities of $5^{\text {th }}$ year students who had completed the SL experience and were involved in ongoing community interactions and reflective writing were compared with the abilities of $4^{\text {th }}$ year students who currently were enrolled in the SL course. Students were matched as closely as possible for age. All students were involved in 12 weeks of ongoing community work that complemented their coursework. The community experiences of the $5^{\text {th }}$ year students matched those of the $4^{\text {th }}$ year students in terms of service time, documentation of their experiences and guided reflection. Thus, the differentiating factor for the two groups was the length of exposure to the concepts of SL and community-based learning.

There were no significant differences in overall critical thinking abilities within each group of students before and after their community experiences. However, there was a significant difference between the two groups, with the $5^{\text {th }}$ year students having higher overall critical thinking scores, particularly in their ability to deduce conclusions and evaluate arguments. As age was not a significant factor, it appeared that the additional year of experience for the $5^{\text {th }}$ year students enabled them to consolidate the benefits of their previous SL experience and community engagement. Becoming a skilled critical thinker is an ongoing, multi-layered, complex, and non-linear process. It takes time to gain experience and confidence in the external or internal dialogue necessary to ask relevant questions, consider a range of alternative possibilities, investigate the evidence for these possibilities without bias, evaluate inconsistencies and correct faulty assumptions, formulate accurate conclusions, and re-work these layers when new evidence arises (Bringle \& Hatcher, 1999; Mezirow, 1990; Paul, 1992; van Gelder, 2005). As critical thinking and reflective inquiry are integral to SL, Gelmon (2007) cautioned that the effectiveness of SL needs to be measured over substantial periods of time, particularly over periods longer than one 16-week semester when practical. Thus, another aspect of higher overall critical thinking scores for the $5^{\text {th }}$ year students could be that changes in the critical thinking abilities of the $4^{\text {th }}$ year students were measured too soon.

Further evidence of the need to measure critical thinking abilities over longer periods of time may be found in the pioneering work of Dewey (1933) and subsequent work by Freire (1993). These investigators viewed perplexity, or educated confusion, as a starting point for learning. This perplexity relates to the different ways in which students analyze material they do not understand compared to their analysis of material they believe they know. Increasing insight into the complexities of critical thinking and examination of the information they rely on to infer, assume, deduce, interpret, and argue a position or belief may result in a period of increased questioning or confusion for many students. This increased insight coupled with increased questioning may explain the profile of post SL responses for the $4^{\text {th }}$ year students.

Despite the degree of difference between the $5^{\text {th }}$ and $4^{\text {th }}$ year students, the pattern of their responses across the five critical thinking subtests was remarkably similar before they began their community experiences. Following their SL experiences, the $4^{\text {th }}$ year students showed a notable decrease in their ability to recognize assumptions and make appropriate deductions. Through their SL experiences, the $4^{\text {th }}$ year students may have realized, positively, that critical and non-judgmental thinking is difficult and demanding. Further, that it requires much active and deliberate practice, is a continuous process, and cannot develop fully until its theoretical foundation is understood and applied (van Gelder, 2005). This realization may have occurred at or close to the time of the post-SL assessment and affected students' confidence in responding to the re-administration of the Watson-Glaser test. Caught in this important and necessary period of questioning, re-consideration and re-evaluation, the $4^{\text {th }}$ year students may have been less sure of their ability to make inferences, recognize correct or faulty assumptions, and form appropriate deductions (Mezirow, 1990, Nokes, Nickitas, Keida, \& Neville, 2005), and their post-SL scores reflected this.

In their perplexion and confusion, the $4^{\text {th }}$ year students may have recognized that they had been viewing the world though a lens which blurred reality or that was too narrowly focused. It is this discomforting recognition that, when followed through, enables students to begin to consider alternative ways of thinking based on the evidence of 
experience. The issue of perplexity highlights the need for supportive instructors who are skilled in facilitating deep reflective inquiry (Bringle \& Hatcher, 1999; Eyler, 200; Felten et al., 2006; Kolb, 1984; Paul et al., 1995) rather than a surface approach to learning, as students develop their critical thinking skills. Students must be supported in their ability to apply and re-apply the skills of learning, unlearning, and new learning throughout life in any reflective, critical thinking process (Carnegie Report, 2006). This is particularly important for students involved in SL as this challenging experience frequently focuses on working with people who are disadvantaged in some manner.

Unlike traditional methods of learning, SL employs a collaborative approach where the responsibility for learning is shared between students and instructors using democratic and scaffolded processes (Clayton \& Ash, 2004). Within this collaboration, students need careful and respectful guidance as they gain insight into what they do, and do not know, and become increasingly able to self-monitor, correct, and expand their thinking (Carnegie Report, 2006; Clydesdale, 2009; Gokhale, 1995; Paul \& Elder, 2008; van Gelder, 2005). While many educators understand and advocate the importance of deep and collaborative learning, few have been shown to actually implement this approach in their classes (see, for example, Scholten, 2001).

In the present study, the instructor who taught the $4^{\text {th }}$ and $5^{\text {th }}$ year students had participated in a series of faculty courses focused on informed reasoning, careful listening, and critical, reflective thinking. However, she may not have achieved the experience required to facilitate the needed deliberate practice and argument mapping constructs integral to critical thinking (van Gelder, 2005). Thus, she could have used an unintended, but limited, approach to shared responsibility and deep reflective inquiry in her guidance and feedback to students. An influential factor in students' motivation to participate in and benefit from their SL experience is the experience they have while their SL is underway (Carnegie Report, 2006). In addition, students interested in civic engagement can influence one another positively or negatively as they share and reinforce one another's skills and attitudes (Winston \& Zimmerman, 2003). Thus, any limitation in the instructor's approach could have been an additional factor in the $4^{\text {th }}$ year students' decreased scores in recognizing assumptions and deductive reasoning. If this were the case, however, one might expect to see a similar influence on the abilities of the $5^{\text {th }}$ year students. It is critical for instructors using experiential learning to avoid biasing class time in favor of covering academic material at the expense of collaborative learning and reflective inquiry (Gokhale, 1995). Van Gelder (2005) commented on the unfortunate consequence of students frequently being left to explore important issues on their own when imbalances in didactic teaching versus reflective learning occur. Further, instructors need to facilitate learning in ways that best fit the students' learning needs (Clydesdale, 2009).

An additional factor affecting the measurement of students' critical thinking abilities could have been the tool used. The Watson-Glaser Critical Thinking Appraisal (Watson \& Glaser, 1980) was selected due it its reported validity and reliability and its two available forms with documented test-retest reliability (Bringle et al., 2004). Clearly both groups contained one or more students who scored at or near the maximum possible points for each subtest. However, each group also contained students who appeared to struggle with the material. Although the Watson-Glaser was valid and reliable, it may not have been constructed for test-retest reliability over the short period of time for which it was used. It also may not have been sensitive enough to measure small changes over time.

To investigate the $4^{\text {th }}$ year students' critical thinking abilities further, their reflective writing was examined. In their weekly journal entries, students reflected on the challenging questions posed by Eyler and Giles (1999). Specifically, they were asked to document (a) what they saw and did, (b) how they felt, (c) any assumptions or beliefs that were challenged or changed, and (d) how their experiences related to what they were learning in class. Journal entries showed the movement of many students through (a) judgment, (b) feelings of no accountability, (c) expressions of concern, and then (d) openness to listening and acknowledging their role in perpetuating prejudicial thinking. These are important steps in the development of critical thinking and cultural competence. Eyler (2005) argued that such reflective insights can serve as a powerful measure of the impact of SL on students' civic engagement. Descriptive data also can illustrate subtle changes in thinking over time and the development of intellectual virtues, attitudes and morals. Such data can be explored systematically through a checklist for reasoning (Paul \& Elder, 2008), manual content analyses as used by Landis et al. (2007), or computerized analyses such as $\mathrm{NVIVO}_{7}$ software (QSR International, 2007). These data analyses can provide a valuable complement to and clarification of quantitative data (Patton, 2002) in demonstrating how the achievement of higher order critical 
thinking is an ongoing process and not a product (Paul, 1992), as students reflect on their exposure to issues of cultural diversity during and following SL experiences.

\section{CONCLUSIONS}

The possibility that Service-Learning outcomes might vary overtime, with initial confusion followed by eventual gains in maturity of thinking, thus contributing to students' intellectual development and cultural competence, appears an intriguing one and worthy of more detailed examination. This pilot work has identified critical factors that need to be addressed in future studies to explore the effects of SL. These factors include:

a) Measuring the effects of SL experiences longitudinally as well as within a semester

b) Having skilled instructors who are able to address both reason and emotion in a systematic reflective learning process, and to measure this in ways that take into account the non-linear development of critical thinking skills, and

c) Analyzing both quantitative and qualitative data to capture the full extent of students' learning and to evaluate the role of SL in facilitating critical thinking and cultural competence.

\section{AUTHOR INFORMATION:}

Dr. Lyn Goldberg is an Associate Professor at Wichita State University. She is an active member of the International Society for the Scholarship of Teaching and Learning (ISSoTL) and is interested in exploring ways in which to measure outcomes in experiential learning.

Dr. Kathy Coufal is Professor and Chair of the Department of Communication Sciences and Disorders at Wichita State University. Her interests and professional experiences have focused on early intervention for children with developmental disorders and their families.

\section{REFERENCES}

1. Bowen, F., \& Blackmon, K. (2003). Spirals of silence: The dynamic effects of diversity on organizational voice. Journal of Management Studies, 40(6), 1393-1400.

2. Boyte, H. (2006, February). Democracy is a way of life: Organizing for cultural change. Presentation at Missouri State University, Springfield, MO.

3. Bringle, R.G., \& Hatcher, J.A. (1999, Summer). Reflection is service-learning: Making meaning of experience. Educational Horizons, 179-185.

4. $\quad$ Bringle, R.G., Phillips, M.A., \& Hudson, M. (2004). The measure of service learning: Research scales to assess student experiences. Washington, DC: American Psychological Association.

5. Carnegie Report. (February 2006). Higher education: Civic mission \& civic effects. Washington, DC: Carnegie Foundation for the Advancement of Teaching and the Center for Information and Research on Civic Learning and Engagement (CIRCLE).

6. Cheng, L. (2005). Successful clinical management requires cultural intelligence. Perspectives on Neurophysiology and Neurogenic Speech and Language Disorders, 15(1), 16-19.

7. Clayton, P.H., \& Ash, S.L. (2004). Shifts in perspective: Capitalizing on the counter-normative nature of service-learning. Michigan Journal of Service-Learning, 11(1), 59-70.

8. Clydesdale, T. (2009, January 23). Wake up and smell the new epistemology. The Chronicle of Higher Education, 55(20), B7.

9. Cornell-Swanson, L. (2006, November). Student reflections on racism and white privilege. Presentation at the International Society for the Scholarship of Teaching and Learning, Washington, DC.

10. Dewey, J. (1933). How we think: A restatement of the relation of reflective thinking to the educative process. Boston, MA: D.C. Heath and Company.

11. Escalera, E.A. (2006, November). Reducing student discrimination: Applying the stigma threat hypothesis to the classroom environment. Presentation at the International Society for the Scholarship of Teaching and Learning, Washington, DC. 
12. Eyler, J. (2005, February). Reflecting on service-learning. Presentation at Missouri State University, Springfield, MO.

13. Eyler, J., \& Giles, D. (1999). Where is the learning in service-learning? San Francisco, CA: Jossey-Bass.

14. Facione, P.A., \& Facione, N.C. (1994). Holistic critical thinking scoring rubric. Retrieved March 12, 2009, from http://www.insightassessment.com/HCTSR.htm.

15. Felten, P., Gilchrist, L.Z., \& Darby, A. (2006, Spring). Emotion and learning: Feeling our way toward a new theory of reflection in service-learning. Michigan Journal of Community Service Learning, 38-46.

16. Freire, P. (1993). Pedagogy of the oppressed. New York, NY: Continuum Books.

17. Garrison, D.R. (1992). Critical thinking and self-directed learning in adult education: An analysis of responsibility and control issues. Adult Education Quarterly, 42(3), 136-148.

18. Gelmon, S. (2007). How do we know that our work makes a difference? An overview of assessment of service-learning. Presentation at Missouri State University, Springfield, MO.

19. Gokhale, A. (1995). Collaborative learning enhances critical thinking. Journal of Technology Education, 7(1), 22-31.

20. Goldberg, L.R. (2007). Service-learning as a tool to facilitate cultural competence. Perspectives on Communication Disorders and Sciences in Culturally and Linguistically Diverse Populations, 14(1), 3-7.

21. Goldberg, L.R., McCormick Richburg, C., \& Wood, L. (2006). Active learning through service-learning. Communication Disorders Quarterly, 27(3), 131-141.

22. Good, L. (2005, Spring). Doing diversity through service learning. Academic Exchange Quarterly, 70-74.

23. Gurin. P., Dey, E.L., Hurtado, S., \& Gurin, G. (2002). Diversity and higher education: Theory and impact on educational outcomes. Harvard Education Review, 72(2), 330-366.

24. Hatcher, J.A., \& Bringle, R.G. (1997, Fall). Reflection: Bridging the gap between service and learning. College Teaching, 45(4), 32-37.

25. Howe, N., \& Strauss, W. (2000). Millenium rising: The next great generation. New York, NY: Vintage Books, Random House Publishers.

26. Huston, T. (2006, November). Effects of bias in classroom learning. Presentation at the International Society for the Scholarship of Teaching and Learning, Washington, DC.

27. Kirsch, I., Braun, H., \& Yamamoto, K. (2007). America's perfect storm: Three forces changing our nation's future. Princeton, NJ: Educational Testing Service.

28. Kolb, D.A. (1984). Experiential learning. Englewood Cliffs, NJ: Prentice Hall.

29. Landis, M., Swain, K.D., Friehe, M.J., \& Coufal, K.L. (2007). Evaluating critical thinking in class and online: Comparison of the Newman method and the Facione rubric. Communication Disorders Quarterly, 28(3), 135-143.

30. Langsdorf, L. (1988). Ethical and logical analysis as human science. Human Studies, 11, 45-48.

31. Laroche, L. (2002). Managing cultural diversity in technical professions. St. Louis, MO: Elsevier Butterworth-Heinemann.

32. Litke, R.A. (2002). Do all students “get it?": Comparing students' reflections to course performance. Michigan Journal of Community Service Learning, Spring, 27-34.

33. Mezirow, J. (1990). Fostering critical reflection in adulthood: A guide to transformative and emancipator learning. San Francisco, CA: Jossey-Bass.

34. Newman, D.R., Johnson, C., Cochrane, C., \& Webb, G. (1996). An experiment in group learning technology: Evaluating critical thinking in face-to-face and computer-supported seminars. Retrieved March 12, 2009, from http://www.helsinki.fi/science/optek/1996/nl/newman.htm/contents.html.

35. Nokes, K.M., Nickitas, D.M., Keida,, R., \& Neville, S. (2005). Does service-learning increase cultural competency, critical thinking, and civic engagement? Journal of Nursing Education, 44(2), 65-70.

36. Oblinger, D.G., \& Oblinger, J.L. (Eds., 2005). Educating the next generation. Educause e-book, http://net.educause.edu/ir/library/pdf/pub7101.pdf accessed February 10, 2009.

37. Patton, M.Q. (2002). Qualitative research and evaluation methods. Thousand Oaks, CA: Sage Publications.

38. Paul, R. (1992). Critical thinking: What every person needs to survive in a rapidly changing world. Santa Rosa, CA: The Foundation for Critical Thinking.

39. Paul, R., Binker, A.J.A., Martin, D., Vetrano, C., \& Kreklau, H. (1995). Critical thinking handbook. Santa Rosa, CA: The Foundation for Critical Thinking.

40. Paul, R., \& Elder, L. (2008). The miniature guide to critical thinking: Concepts and tools. Santa Rosa, CA: The Foundation for Critical Thinking. 
41. QSR International (2007). Available from http://www.qsrinternational.com/products_previousproducts_nvivo7.aspx.

42. Scholten, I. (2001). Teachers' conceptions of their role in improving preparation for clinical work in dysphagia. American Journal of Speech-Language Pathology, 10, 343-357.

43. Settle, A.A., \& Smith, C.J. (2008). Using service-learning as a higher education teaching strategy for health and physical education as well as the athletic setting - a step by step approach. College Teaching Methods \& Styles Journal, 4(9), 5-9.

44. Smith-Campbell, B. (2005). Health professional students' cultural competency and attitudes toward the poor. Journal of Allied Health, 34, 44-50.

45. Stevens, J. P. (2002). Applied multivariate statistics for the social sciences (4th ed.). Mahwah, NJ: Lawrence Erlbaum Associates.

46. United States Department of Education (2006). A test of leadership: Charting the future of U.S. higher education. Washington, DC: Author.

47. Van Gelder, T. (2005, Winter). Teaching critical thinking: Some lessons from cognitive science. College Teaching, 53(1), 41-46.

48. Watson, G.B., \& Glaser, E.M. (1980). Watson-Glaser critical thinking appraisal. San Antonio, TX: Psychological Corporation.

49. Winston, G.C., \& Zimmerman, D.J. (2003). Peer effects in higher education. National Bureau of Economic Research Working Paper \#9501.

50. Zinger, L., \& Sinclair, A. (2008). Implementing service learning: From nutrition education into community action. Journal of College Teaching \& Learning, 5(12), 1-5. 
NOTES 